\title{
Housing and the UK election manifestos for 2019: Reclaiming established positions, some novelty but more questions than answers
}

\author{
Kenneth Gibb* \\ University of Glasgow
}

While the general election was called unexpectedly, it was keenly anticipated and did not in any way hinder political parties producing a range of manifestos with more or less detailed pledges and proposals over a wider range of policy areas. This was equally true of housing and related policy areas (e.g. social security). ${ }^{1}$

I am not going to get bogged down in the minutiae or details of all of the housing manifesto claims; rather I want to focus on a number of larger themes and then focus on just a couple of key policy areas: affordable housing supply and private renting reform. I think there are a small number of interesting and novel ideas and these are also briefly touched on.

The first thing that strikes me looking at the two major UK parties is a sense of a retreat to well understood traditional party positions on housing. The Tories' return to policies to boost home ownership is on the one hand a reflection of the genuine aspirational problem many now face about accessing home ownership, but also allows the Conservatives to reset to tried and tested ideological mantras about the innate nature of home ownership (i.e. something worth subsidising and supporting). Equally, Labour seems comfortable promoting a large scale and sustained social house building programme led from the council sector, via local authority-led housing planning and including ending the Right to Buy. By the same token the Conservatives can hardly bring themselves to mention social housing investment. Consequently, there is a 1970 s or 1980 s feel to the broad strokes of the two parties' standpoint over the macro direction of housing policy.

The second point is to note the asymmetric and rather unsatisfactory way that housing is impacted on by the presence of the devolved nations (by which I mean from an election manifesto perspective rather than substantively!). Generally speaking, housing is largely devolved and this is probably most noticeable in Scotland and also in Wales, where in both countries' policy is diverging increasingly from that in England. This is reflected in the manifestos but in a rather haphazard and inconsistent way. The Scottish Nationalists generally view their manifesto as a discussion of UK Parliament issues that affect Scotland, and because of housing devolution, they do not deal directly with housing. Rather, the focus is on for instance reforming Universal Credit and other (reserved) social security policy they do not like - similar proposals can be found in Northern Ireland for things like ending the bedroom tax. The sense is that the real fight over housing will be in the devolved elections in 2021 (also apparent in the Welsh manifestos). On the other hand, Scottish Labour and Welsh Labour use this election as an opportunity to set out the policy stall for 2021 . Inevitably, this means 
p. 64. Housing and the UK election manifestos for 2019: Reclaiming established positions, some novelty but more questions than answers

that many of the big debates from a housing perspective are really concerned with England $^{2}$ - though whether this captures adequately regional differentiation within England is another question.

The third dimension that is worth raising is just how do we go about assessing the merits of competing manifesto claims? I think there are multiple criteria that should inform how we respond to policy proposals. What evidence is there to back up a claim? How credible are the proposals in terms of actually being able to deliver what they claim they will (it is rarely enough to simply say 'we will end' rough sleeping)? What is the time frame for the policy outcomes and how seriously has it been costed (and where do the resources come from?)? Does the policy improve the housing system as a whole and is it sufficiently aware of complexity, unanticipated consequences and feedback loops, etc.? Has it been adequately audited in terms of fairness/social justice and sustainability outcomes? Of course, it is naive to expect to see this kind of detail but I would argue that, if we do not, we should not give a policy a free pass. Federal reforms that change regulatory policies in the United States must do a rigorous evaluation of their impacts. This would go far beyond our ex ante impact assessments and would be a welcome meta manifesto pledge - one I think we will wait long for.

Turning to the specific housing policy focus, building more affordable homes is subsumed within the non-specific net additions target proposed by the Conservatives (a million homes over the five years of the next Parliament). Presumably the existing plans of Homes England will simply roll on and there is a white paper pledged to continue supply. Labour plans annually to build 100,000 units of housing by councils for social rent with a greater emphasis on local planning and needs estimation locally, tied to other incentives to facilitate social housing supply (e.g. ending the RTB and developing an 'England sovereign land trust'). They will also outlaw social cleansing by ensuring that existing residents of estate regeneration projects are re-offered new property on the same terms as their existing rights. The Liberal Democrats seek to build 300,000 homes a year by 2024 , of which 100,000 will be for social rent (supported by a contribution from an additional capital infrastructure budget worth $£ 130$ billion - but to be spread over a range of infrastructure activities). The Green Party want to build 100,000 social council homes per annum, with both lifetime tenancies and construction to a passiv haus standard.

How might we assess these proposals? We know from Scottish experience that RTB abolition is an important necessary element in building council homes, which in the case of Scotland had little negative impacts. At the same time, Scotland deployed substantial capital grants to deliver new council housing (and housing association build) - something recognised by the recent submissions by the NHF and Crisis regarding meeting unmet housing need in England. On the flipside large affordable supply programmes have been numbers-focused and there must always be safeguards regarding the quality of both build and placemaking. I think there is a trade-off here between the worthy desire to meet unmet need and reduce unaffordability, as set against a lack of detail on how these programmes will operate and how potential spillovers and induced incentives will be managed. Sometimes there is too little detail or just, as with the Conservatives, an implicit continuation of what is currently underway (always the right of the governing party but it would be helpful if other parties explicitly engaged with what they think does and does not work from the current offer of housing policies).

Private renting reform is another interesting cross-party issue. Again, it is in part driven by policy divergence in Scotland and Wales (as well as by clamour for change in England). The Conservatives have restated their commitment to abolishing 'no fault' evictions. At the same time, however, they say they will seek to strengthen rights of possession for 'good' landlords. Labour go further and in a different direction - offering 
p. 65. Housing and the UK election manifestos for 2019: Reclaiming established positions, some novelty but more questions than answers

open-ended tenancies, nationwide rent increase limitations plus opportunities for cities to operate additional controls. There is also a commitment to minimum standards in the sector, as well as new powers for councils to penalise bad landlords, nationwide licensing and regulations that can be deployed by councils over short term letting. The Lib Dems pledge a government-backed deposit loan to assist young renters. They also propose a three-year standard tenancy with inflation-related rent increases. The Lib Dems also favour licensing to help address 'rogue' landlords.

Longer tenancies (compared to the status quo in England) are clearly generally favoured and may now actually happen, after several false dawns. The opposition parties favour different degrees of rent limitation, though it is less clear the evidence base on which they are proposed or indeed their wider system effects (I am being agnostic here: I just want to know how they are evidenced). For me, one of the key questions that I feel is unsatisfactorily answered by all three parties is how to ensure that new non-rent regulations to improve tenancies and relations with landlords, etc. can be consistently enforced. How will regulation be implemented and can any party guarantee that being a tenant in a cash-poor council will receive the same protection as someone in a wealthy and well-resourced local authority?

There were a few eye-catching novel ideas among the manifestos. The Conservatives might be back on the discounted first time buyer route but they also are proposing a long term fixed rate mortgage model (presumably securitised) which could help first time borrowers purchase up to 95 per cent loans. Much more detail is required on this. The other interesting new Conservative idea is to suggest that private tenants can operate a lifetime rental deposit, guaranteed by government. The Lib Dems propose a rent to own model whereby rental payments accumulate over time to create a stake in one's home which can eventually be owned outright. This seems to raise all manner of questions about incentives and the fairness of such ideas. Again, much more detail required. The striking ideas under Labour's proposals are I think in the land and planning sphere: they continue to believe the 'use it or lose it' powers will be important to speed up development in a timely way rather than lose planning permission (are the behavioural assumptions in this proposal actually borne out?). The other aspect of interest is the sovereign land trust with powers to buy land more cheaply for low cost housing - which sounds like a form of land value uplift capture and is worth further development and analysis.

Finally, what about the dogs that did not bark? I did not see any explicit connections between Brexit and the delivery of housing policies e.g. via impacts on market demand or on the construction industry. There is also little said about more radical policy e.g. about progressive housing taxation, meaningful i.e. structural housing benefit reform, or more tenure-neutral reforms, etc. At one level this might be viewed as simply not politically credible or feasible. Perhaps that is true but I would direct readers to the Housing to 2040 consultation underway in Scotland just now wherein Government principles for a well-functioning housing system include radical proposals such as legislating to enforce housing as a human right, pursuing policies that will stabilise house prices and seek to rebalance housing as a consumption activity rather than as a store of wealth. These may be aspirational rather than deliverable goals at this point but it is a start, and a trajectory simply not to be found in the manifestos here, which do not actually have a transformative agenda on that sort of a scale. 
p. 66. Housing and the UK election manifestos for 2019: Reclaiming established positions, some novelty but more questions than answers

\section{Notes}

1 In addition to reading manifestos, there are a lot of commentary pieces out there including for housing aspects of Party proposals. The piece here has been informed in particular by member briefing by the Chartered Institute of Housing, by https://www.insidehousing.co.uk/insight/insight/general-election-2019-up-to-datehousing-news-commentary-and-analysis-in-one-place-64188, https://www.housing.org.uk/get-involved/promoting-our-sector/general-election2019/, and the https://www.instituteforgovernment.org.uk/manifesto-tracker

2 As ever, Northern Ireland is different with housing featuring (and with different emphases) in a more devolved setting in the manifestos of Sinn Fein, the Alliance and the DUP.

\section{Acknowledgements}

I would like to thank our knowledge exchange associates, particularly, Gareth Young, Joe Frey and Bob Smith - who helped source materials for this short commentary. All errors and opinions remain my responsibility alone.

* Correspondence address: Professor Kenneth Gibb, R243 Level 2, Urban Studies, 29 Bute Gardens, Glasgow G12 8RS. Email: ken.gibb@glasgow.ac.uk. 